\title{
Needs and preferences for nutrition education of type 2 diabetic adults in a resource-limited setting in South Africa
}

\author{
Authors: \\ Jane W. Muchiri ${ }^{1}$ \\ Gerda J. Gericke ${ }^{1}$ \\ Paul Rheeder ${ }^{2}$ \\ Affiliations: \\ ${ }^{1}$ Department Human \\ Nutrition, University of \\ Pretoria, South Africa \\ ${ }^{2}$ School of Health Systems \\ and Public Health, University \\ of Pretoria, South Africa \\ Correspondence to: \\ Jane Muchiri \\ Email: \\ jane.muchiri@up.ac.za \\ Postal address: \\ Private Bag X323, Pretoria \\ 0001, South Africa \\ Dates: \\ Received: 21 July 2011 \\ Accepted: 13 July 2012 \\ Published: 18 Oct. 2012 \\ How to cite this article: \\ Muchiri, J.W., Gericke, G.J. \\ \& Rheeder, P., 2012, 'Needs \\ and preferences for nutrition \\ education of type 2 diabetic \\ adults in a resource-limited \\ setting in South Africa', \\ Health SA Gesondheid 17(1), \\ Art. \#614, 13 pages. http:// \\ dx.doi.org/10.4102/hsag. \\ v17i1.614
}

C) 2012. The Authors. Licensee: AOSIS OpenJournals. This work is licensed under the Creative Commons Attribution License.
Diabetes self-management education is crucial in diabetes care. Education that is tailored to the needs of the patient is considered the most effective in improving health outcomes. Diet, a critical element of diabetes treatment, is reported as the most difficult to adhere to by both patients and health professionals. Tailored nutrition education (NE) could benefit diabetic individuals with low socio-economic status, who are amongst those noted to have poor health outcomes. This qualitative interpretive phenomenological study aimed to explore and describe the NE needs of adults with type 2 diabetes mellitus to guide development of a tailored NE programme for resource-poor settings. Participants were 31 non-insulindependent type 2 diabetic patients (convenience sample) and 10 health professionals. Focus group discussions using semi-structured questions were held with the diabetics, and openended self-administered questionnaires were used with the health professionals. Data analysis was done using Krueger's framework approach. Disease-related knowledge deficits and inappropriate self-reported dietary practices, including intake of unbalanced meals, problems with food portion control and unsatisfactory intake of fruits and vegetables, were observed. Recommendations for the NE programme included topics related to the disease and others related to diet. Group education at the clinic, a competent educator and comprehensive education were indicated by the patients. Participation of family and provision of pamphlets were aspects recommended by patients and health professionals. Barriers that could impact the NE included financial constraints, food insecurity, conflict in family meal arrangements and access to appropriate foods. Support from family and health professionals and empowerment through education were identified as facilitators to following dietary recommendations by both groups of participants. Knowledge deficits, inappropriate dietary practices and barriers are issues that need addressing in an NE programme, whilst the suggestions for an NE programme and facilitators to dietary compliance need to be incorporated.

Onderrig in die selfbestuur van diabetes is essensieel in diabetessorg. Onderrig wat spesifiek ooreenkomstig die behoeftes van die pasiënt aangepas is, word die mees doeltreffend in die verbetering van gesondheiduitkomste geag. Dieet, ' $n$ kritiese element in diabetesbehandeling, word deur pasiënte en gesondheidpraktisyns as die moeilikste beskou om na te volg. Spesifiek beplande voedingonderrig kan tot voordeel van lae sosio-ekonomiese diabete wees wat deel van diegene wat swak gesondheiduitkomste toon, uitmaak. Die doel van hierdie kwalitatiewe interpreterende fenomologiese studie was om die voedingonderrigbehoeftes van volwassenes met tipe 2 diabetes mellitus te ondersoek en te beskryf ten einde die ontwikkeling van 'n voedingonderrigprogram wat op hulpbrondbeperkte omgewings afgestem is, te rig. Een en dertig nie-insulien afhanklike tipe 2 diabetes pasiënte (geriefsteekproef) en 10 gesondheidpraktisyns was evalueer. Fokusgroepbesprekings deur gebruikmaking van semi-gestruktureerde vrae, is met die diabete gehou. Self-geadministreerde oop-eindigende vraelyste is deur die gesondheidpraktisyns voltooi. Data-analise is volgens Krueger se raamwerkbenadering gedoen. Siekteverwante kennisgapings en ontoepaslike self-gerapporteerde dieetpraktyke, insluitend ongebalanseerde maaltye, probleme met porsiekontrole en ontoereikende inname van groente en vrugte is gerapporteer. Aanbevelings vir die voedingonderrigprogram het onderwerpe verwant aan die siekte en die dieet ingesluit. Die pasiënte het groeponderrig by die kliniek, 'n bevoegde onderrigpraktisyn en omvattende onderrig verkies. Die pasiënte en die gesondheidpraktisyns het gesinsdeelname en die beskikbaarstelling van pamflette aanbeveel. Struikelblokke wat negatief op die voedingonderrigprogram kon inwerk, het finansiële beperkinge, voedselinsekuriteit, konflik met gesinsmaaltydreëlings en toegang tot geskikte voedsels ingesluit. Ondersteuning van die gesin en gesondheidpraktisyns, sowel as bemagtiging deur kennis is as fasiliteerders ter bevordering van die navolging van dieetaanbevelings deur beide groepe deelnemers geïdentifiseer. Tekortkominge in kennis, ontoepaslike dieetpraktyke en struikelblokke is aspekte wat in 'n voedingonderrigprogram aangespreek behoort te word. Voorstelle wat vir die voedingonderrigprogram en fasiliteerders gemaak is vir dieetnavolging, behoort in die program ingesluit te word. 


\section{Introduction Background}

Type 2 diabetes mellitus is increasing in epidemic proportions (Shaw, Sicree \& Zimmet 2010) and is now considered a global public health problem (Zimmet 2003). This condition, that was traditionally associated with the affluent, now affects populations from all socio-economic levels (Gwatkin, Guillot \& Heuveline 1999; Zimmet 2003). Individuals of low socioeconomic status are amongst those noted to experience worse long-term diabetes management outcomes (Roper et al. 2001; Levetan, Levitt \& Bonnici 1997). This is attributed to more barriers to self-care, including limited access to continuous quality health care (Glazier et al. 2006; Cox et al. 2004). The complications of poorly controlled diabetes pose a serious social and financial burden, especially to those in resourcelimited settings. Therefore special attention as well as effective and feasible diabetes management strategies should be directed to populations in resource- limited settings.

Diabetes self-management education (DSME) is a critical element of diabetes care (Funnell et al. 2009). A vast number of studies have shown that DSME (Ellis et al. 2004; Norris, Engelgau \& Narayan 2001; Norris et al. 2002) including nutrition education (NE) (Pastors et al. 2002; Shabbidar, Fathi \& Shirazifard 2006) significantly improves health outcomes.

Planning tailored diabetes education programmes is only possible if one has a thorough understanding of the target group. A comprehensive needs assessment is thus crucial (Muchiri, Gericke \& Rheeder 2009; Glazier et al. 2006 Brown et al. 2002). Determination of the education needs of the target population(s) is one of the DSME standards stipulated by organisations dealing with diabetes (International Diabetes Federation 2009; Funnell et al. 2009).

Qualitative studies have increasingly been used to assess the needs and preferences for education of the target group as well as evaluating education programmes (Benavides-Vaello et al. 2004; Dye, Haley-Zitlin \& Willoughby 2003). Focus groups in particular have been used successfully in developing or adapting diabetes self-management interventions, especially in low-income populations and minority groups (Vincent et al. 2006; Rosal et al. 2004). The informal style of focus groups is conducive to identifying barriers to care, exploring health beliefs, identifying education needs and in gathering information to improve intervention programmes (Blancard et al. 1999; Benavides-Vaello et al. 2004). The synergy promoted by the group interaction produces ideas and statements which could not be generated with other types of methods (Rabiee 2004; Kidd \& Parshall 2000). Respondents can qualify, clarify and build upon responses, thus conveying more thoughtful and in-depth information (Benavides-Vaello et al. 2004; Kidd \& Parshall 2000).

Benavides-Vaello et al. (2004), in a study based on focus groups with Mexican Americans with type 2 diabetes, found that participants were able to identify specific diabetes topics and issues requiring attention. The results were used in planning a targeted education programme. Blancard et al. (1999) found knowledge deficits and financial problems to be the major factors affecting diabetes self-management amongst African Americans with type 2 diabetes. The study also identified group education, hospital setting and clinicians as 'experts' as desirable characteristics of an education programme. Similarly, other studies have obtained views of and preferences for education as well as factors that could influence education and ultimately diabetes selfmanagement (Dye et al. 2003; Brown \& Hanis 1999; Vincent et al. 2006; Two-Feathers et al. 2007; Rosal et al. 2004).

\section{Problem statement}

Although diet is an essential component of diabetes care, dietary adherence is reported by both health professionals and patients to be the most difficult amongst diabetes self-care areas (Sullivan \& Joseph 1998; Vijan et al. 2005, Nagelkerk, Reick \& Meengs 2006; Shultz et al. 2001; Rosal et al. 2004). This problem is particularly apparent in low-income groups (Cox et al. 2004). There is therefore a need for effective NE that will assist diabetic individuals overcome barriers to dietary self-care.

Education that is culturally relevant (Brown et al. 2002; Anderson-Loftin et al. 2002) and tailored to the needs and abilities (Clark et al. 2004; Two Feathers et al. 2007) of the patient has been shown to be effective in improving health outcomes. In sub-Saharan Africa there is a paucity of data or literature on structured, tailored NE programmes targeting individuals with diabetes mellitus. In addition, views of healthcare providers on the education needs of their diabetic patients have received little attention. There is therefore a need to establish the needs and preferences of individuals with diabetes for NE, in order to plan targeted education programmes.

\section{Aim and objectives of the study}

The purpose of this study was to explore and describe the NE needs of adults with type 2 diabetes mellitus in Moretele sub-District, South Africa, to guide the development of a target group-tailored NE programme. The specific objectives were to: (1) establish the current understanding of diabetes and its management, (2) examine the self-reported current dietary practices and perceived dietary adherence, (3) explore the factors that could impact NE, the perceived barriers and facilitators to dietary compliance, and (4) to elicit recommendations for content and preferred education approaches for an NE programme.

\section{Significance of the study}

This study will provide insight into the issues that need to be addressed in an NE programme that are specific for diabetic adults in the particular study setting and other similar settings. The information generated will contribute to a better understanding of the factors that need to be considered in the nutritional management of diabetes. This includes the planning or provision of NE that is tailored to the needs of diabetic adults in resource-limited settings. 


\section{Definition of key concepts}

Resource-poor setting: A geographical or structural location with limited infrastructure (facilities and services) and highly skilled labour force (specialists). The majority of individuals from these settings have low income and material wealth as well as low literacy levels.

Nutrition education: Any set of learning experiences designed to facilitate the voluntary adoption of eating and other nutrition-related behaviours conducive to health and well-being (America Dietetic Association, 1996).

Needs: In this study needs are perceived or observed problems and issues of concern or interest related to diabetes and diet.

Diabetes self-management education: Ongoing process of facilitating the knowledge, skill and ability necessary for diabetes self-care (Funnell et al. 2009).

\section{Research method and design Design}

An interpretive phenomenological design in the qualitative domain was used. The goal of phenomenology is to understand the world as it is experienced by the individual (Norlyk \& Harder 2010; Lopez \& Willis 2004). Interpretive phenomenology acknowledges expert knowledge as valuable to the inquiry, and therefore the meanings obtained from the inquiry are a blend of those articulated by the participants and the researcher (Lopez \& Willis 2004).

\section{Setting}

The study was done in two community health centres (CHCs) (Makapanstad and Mathibestad) in Moretele Health sub-District, North West Province, South Africa. The CHCs are located in a rural area and are approximately $10 \mathrm{~km}$ apart. They are managed by professional nurses. Physicians visit three times per week for consultations with referred cases. Health education in the CHCs (including nutrition) is mainly offered by nursing professionals. Most of the population $(78.7 \%)$ in the study setting earn an income of less than R1500 per month (USD 217.65) (Moretele Local Municipality 2008/2009).

\section{Population and sampling}

The participants were diabetic adults (male and female) with type 2 diabetes (non-insulin dependent) receiving health care at two $\mathrm{CHCs}$, and the health professionals serving them at these CHCs. Patients aged between 40 and 65 years with at least one year of living with diabetes were included. This age group was selected because type 2 diabetes in adults is usually diagnosed at 40 years and above (International Diabetes Federation 2011), and to have a more homogenous age group excluding the elderly who could have other issues related to old age (Suhl \& Bonsignore 2006). The health professionals should have worked with the patients for at least six months, and were residents of the sub-District, making them knowledgeable about dietary and other healthrelated practices in the study area.

Convenience purposive sampling of diabetic patients was undertaken. All patients attending the clinics during the study period and who met the inclusion criteria were invited to take part if they were able and willing to discuss their diabetes in a group. They were individually approached during their monthly clinic visits by the principal investigator and field worker. All health professionals who met the inclusion criteria (16 in all) were requested to participate in the study.

\section{Data collection methods}

Data collection was done in February-May 2009. Focus group discussions (FGDs) were used for the diabetic population. A semi-structured interview guide with open-ended questions was used (Kidd \& Parshall 2000). A qualified dietitian experienced in group facilitation conducted the FGDs in the local dialect (isiTswana) and also took notes. A trained Tswana-speaking field worker took detailed field notes and also audio-taped the sessions. The principal investigator was also present in all of the FGDs.

Four to 10 diabetic patients participated in each focus group that was held at the CHCs. FGDs were conducted until no new information emerged from consequent groups (Fouche 2005; Rabiee 2004), and a total of five FGDs were held with 31 participants. Debriefing between the research team (principal investigator, moderator, field worker and one other investigator) was done after each focus group to discuss and clarify any issues arising (Speziale \& Carpenter 2007; Kidd \& Parshall 2000).

Self-administered questionnaires with a total of 14 openended questions (two of which also included a closed-ended question) were used with the health professionals. The questions addressed adherence to dietary recommendations by patients, barriers and facilitators to dietary adherence of patients, and recommendations for an NE programme.

\section{Data analysis}

Data from FGD interviews were transcribed verbatim in the Tswana language by an experienced transcriptionist and then translated into English. The moderator independently transcribed some of the tapes and translated them into English to confirm the accuracy and representativeness of the transcribed and translated text. The handwritten field notes were also used to confirm data and complement the texts, allowing a fuller analysis of the data (Rabiee 2004; Kidd \& Parshall 2000). Responses from the health professionals' questionnaires were organised by question to allow ease of analysis.

Data analysis was done using Krueger's framework approach (Rabiee 2004). Framework analysis uses a thematic 
approach, in which the themes are allowed to develop both from the research questions and the narratives of the participants (Rabiee 2004). The transcribed text and text from the health professionals' responses were read through several times by the principal investigator to make sense of the whole data, before breaking it into parts. Next data were coded and then grouped according to their meaning to form categories. Frequency, extensiveness and intensity of participants' comments (Rabiee 2004) were used to isolate the major categories. Making connections between the categories (abstraction) identified the most important themes from the data. Citations from the participants were used to demonstrate the link between the data and results.

\section{Trustworthiness}

Credibility of the data was ensured through obtaining data until saturation point; using different participants to generate information (patients and health professionals); using audiotaping and field notes as different methods of data capturing and referential adequacy; using the moderator to confirm the transcribed and translated data; and peer-debriefing with a colleague not involved in the study.

\section{Ethical considerations}

Ethical clearance was obtained from the Research Ethics Committee of the Faculty of Health Sciences, University of Pretoria, South Africa (number 164/2008). Participants in the focus groups were asked for permission to audio-tape the discussions, and were assured of confidentiality.

\section{Potential benefits and harm}

There were no risks or potential dangers to participants in the study, and they were assured of the freedom not to answer any question if they felt uncomfortable. They were also informed that the FGDs or filling in the questionnaires would take up some of their time. Whilst the participants were reimbursed their transport costs, there were no direct benefits to participating in this study. The potential benefit is a targeted NE programme in which the participants will have an equal chance of taking part.

\section{Informed consent}

Participants received detailed information about the study in their preferred language. They were also informed that participation was voluntary; they could refuse to participate or stop participating at any time without giving any reason, and their withdrawal from the study would not affect them in any way. Thereafter they were given opportunity to provide written informed consent or to decline to participate.

\section{Data protection}

Participants were informed that data would be stored in safe custody at the Department of Human Nutrition (UP) offices, where only the research team would have access.
Participants' anonymity was ensured by using study numbers which had no relationship to the participants on all data collection documents.

\section{Results \\ Biographical description of the study groups}

A total of 31 ( 3 males) patients with type 2 diabetes and 10 health professionals participated in the study. The patients' mean age was 55.72 years (range $41-65$ years), and mean duration of disease was 7.62 years (range 1-20 years). All of the health professionals were female nurse practitioners, of whom the majority $(80 \%)$ had worked in the clinics for over two years (Table 1 \& Table 2).

The results of the inquiry are organised as per the five broad themes that were generated from the study objectives and the participants' narratives. The results for the patients are reported as per the focus groups $(n=5)$. A selection of representative statements (quotes) from participants is included to support the results. Quotes from patients' are indicated as group (Gp), participant number and number of participants in that group. For example, Gp 3, P1/8 means group three, participant number one out of eight participants. Quotes for health professionals are indicated as HP with a number assigned to the health professional, such as HP1.

\section{Understanding of diabetes mellitus and its treatment}

Information on the understanding of diabetes and its treatment was obtained through asking patients their views about diabetes in relation to risk factors and/or causes, complications, seriousness, and management. The results indicated that the patients' were aware of some aspects of diabetes mellitus but unaware of other critical aspects. For example, in none of the focus groups was overweight and/or obesity mentioned as a risk factor for diabetes, nor heart disease mentioned as a complication of the disease. Knowledge deficits were also observed in the form of inaccurate information (misinformation) and/or incomplete information. Misinformation on the causes and/or risk factors of the disease ranked the highest (four groups). The factors indicated as causes included diet (sugar, sweet foods) and stress. The following comments by the participants illustrate the confusion concerning the causes of diabetes:

'diabetes is caused by the pancreas, when the pancreas is unable to break down the food' (Gp 3, P6/8).

'I was confused because I grew up not eating sugar' (Gp 2, P4/10).

'it is caused by family problems or your own problems that you do not share with others' (Gp 4, P3/4).

'while the heart is pumping because of the problems you have diabetes easily gets you' (Gp 3, P2/8).

The following participants' comments illustrate their awareness of management strategies:

'it needs one to eat the proper foods' (Gp 1, P1/5).

'you are not supposed to be seated all the time, you should walk some distance' (Gp 4, P2/4). 
TABLE 1: Biographical characteristics of patients $(N=31)$.

\begin{tabular}{|c|c|c|}
\hline Biographical characteristics & $n$ & $\%$ \\
\hline \multicolumn{3}{|l|}{ Age (years) } \\
\hline 40 & 8 & 25.8 \\
\hline 50 & 10 & 32.3 \\
\hline 60 & 13 & 41.9 \\
\hline \multicolumn{3}{|l|}{ Gender } \\
\hline Female & 28 & 90.3 \\
\hline Males & 3 & 9.7 \\
\hline \multicolumn{3}{|l|}{ Education level } \\
\hline None & 3 & 9.7 \\
\hline Std 1-4 & 8 & 25.8 \\
\hline Std 5-7 & 15 & 48.3 \\
\hline Std 8-10 & 3 & 9.7 \\
\hline Post Std 10 & 2 & 6.5 \\
\hline \multicolumn{3}{|l|}{ Employment status } \\
\hline Full time & 1 & 3.2 \\
\hline Part-time & 2 & 6.5 \\
\hline Unemployed & 17 & 54.8 \\
\hline Pensioner & 11 & 35.5 \\
\hline \multicolumn{3}{|c|}{ Duration of disease since diagnosis (years) } \\
\hline $1-4$ & 16 & 51.6 \\
\hline $5-9$ & 4 & 12.9 \\
\hline $10-15$ & 8 & 25.8 \\
\hline $16-20$ & 3 & 9.7 \\
\hline \multicolumn{3}{|l|}{ Management of diabetes } \\
\hline Diet alone & 0 & - \\
\hline Diet and oral hypoglycaemic agents & 31 & 100 \\
\hline
\end{tabular}

$n$, Given as number of patients.

TABLE 2: Biographical characteristics of health professionals $(N=10)$.

\begin{tabular}{lcc}
\hline Biographical characteristic & $\boldsymbol{n}$ & $\%$ \\
Nursing & 10 & 100 \\
Professional & 7 & 70 \\
Auxiliary & 3 & 30 \\
Gender & & \\
Female & 10 & 100 \\
Duration worked at clinic (years) & & \\
$0.6-1$ & 2 & 20 \\
$2-5$ & 4 & 40 \\
$6-10$ & 0 & 0 \\
$11-20$ & 3 & 30 \\
$21-25$ & 1 & 10 \\
\hline
\end{tabular}

$n$, Given as number of health professionals.

'you have to take your medication and not to be too much stressed' (Gp 3, P2/8).

In two focus groups participants seemed to believe there could be a cure for their condition, and that the current treatment is not effective, as illustrated by the following comments:

'a grant and medicine that can help treat this disease' (Gp 3, P1/8).

'we would appreciate if they could make medicine that will make us better' (Gp 2, P4/10).

'we wish they could add something to the treatment of this illness that could help us' (Gp 3, P2/8).

\section{Understanding of diet and adherence}

Information on the understanding of diet and adherence was generated by asking patients what they had been taught or knew about diet and their current dietary practices. All the focus groups seemed to be aware of most dietary recommendations, as per the South African national guidelines for diabetes (Department of Health 2005) and the Food Based Dietary Guidelines (Vorster 2001), as indicated by the following comments:

'We are not supposed to eat oily and fatty foods; we may eat fruits, beans and vegetables' (Gp 2, P2/10).

'If you use sugar it must be just little, even salt' (Gp 4, P4/4).

'You must eat smaller amount of food' (Gp 1, P3/5).

'You should eat a lot of vegetables' (Gp 5, P1/4).

The recommendations for limiting alcohol intake and drinking adequate water were not strongly emphasised, as each was mentioned by one participant only.

Limiting sugar and fat intake was considered important, as indicated by the reported food choices and past dietary changes. All the groups mentioned having reduced fat in cooking and reducing sugar intake:

'I used to use a lot of oil in cooking but now I boil all my vegetables and use a little oil in cooking other foods' (Gp 5, 4/4).

'We no longer use oil, we cook with water' (Gp 4, P3/4).

'I do not use sugar anymore' (Gp 2, P5/10).

Despite the reported reduction in fat intake, the use of saturated fats and high-fat products was identified in two of the focus groups:

'I use full cream milk' (Gp 5, P3/4).

'I use a little Holsum [palm oil] in cooking' (Gp 5, P2/4).

'I use some butter after boiling the vegetables' (Gp 4, P3/4).

Three focus groups indicated that they reduced food portion sizes; however, the participants expressed feeling hungry due to small portions:

'I stopped eating a lot, at first I would feel hungry but now I am getting used' (Gp 2, P6/10).

'I like brown pap [stiff sorghum porridge] but it does not make me full as I have to eat a small amount' (Gp 1, P4/5).

There seemed to be confusion concerning meal frequency and portion sizes, as expressed in the following comments by participants:

'We are supposed to eat very little at a time within a short period, sometimes when you are supposed to eat you are still full and that causes sugar to go high' [Gp 2, P3/10].

'I may eat now and within a short time I want to eat again so I can have energy to do chores' (Gp 4, P2/4).

'I used to eat in the mornings and the next time I will eat at one o'clock or evening, now I have to eat because you cannot stay with an empty stomach' (Gp 1, P3/5).

'We are not supposed to eat to our full stomachs' (Gp 2, P2/10).

Eating balanced meals seemed not to be an important aspect, as none of the groups mentioned consuming a combination 
of all food groups. Starchy foods were the most commonly mentioned as being consumed, followed by milk, fruits and meat. Vegetables seemed not to be consumed regularly. Legumes (apart from peanut butter spread) were not mentioned in any of the groups:

'Most of the times I eat porridge' (Gp 4, P2/4).

'Supper I will eat pap [stiff maize meal porridge] or rice with meat or sometimes vegetables or milk' (Gp 3, P3/8).

'I eat mabela [sorghum] meal, at lunch I eat brown bread; I also sometimes eat apple for snacks' (Gp 1, P5/5).

'In the morning two slices of bread with some peanut butter and tea with low fat milk, around ten o'clock pap or bread, sometimes with fish, an apple around $2 o^{\prime}$ clock, then supper brown or white pap' $^{\prime}(\mathrm{Gp} 5, \mathrm{P} 4 / 4)$

Fruits especially apples were regarded as important snack foods, but many participants (four groups) expressed problems in having adequate fruits:

'we eat snacks like apples when they are available, when we have money' (Gp 4, P1/8).

'we are unable to buy enough foods like fruits' (Gp1, P2/5).

'I eat apples (green) sometimes; I do not eat every day because I do not have money' (Gp 2, P1/10).

Consumption of starchy foods that were higher in fibre appeared to be important in all the groups. However, it was noted that the higher-fibre options were interchangeably used with the lower-fibre options by some participants:

'I normally use brown bread' (Gp 3, P3/8).

'I now eat mabele [sorghum] porridge' (Gp 4, P2/4).

'I eat Jungle Oats in the morning' (Gp 1, P3/5).

'I eat brown or white pap [stiff maize meal porridge], sometimes brown rice' (Gp 5, P3/5).

Misconceptions about the role of food were identified in three focus groups, as indicated by the following statements:

'you must give yourself less food hence a lot of people die and become blind due to diabetes (Gp 1, P1/5).

'it is dangerous because it needs you to eat' (Gp 3, P4/8).

'hence we lose weight because we cannot just eat anything' (Gp 4, P2/4).

The health professionals were asked their views of their patients' adherence to dietary recommendations with regard to proportions, following or not following recommendations (closed-ended question), and areas they found easy or difficult to adhere to (open-ended questions). A summary of the health professionals' views about the patients' adherence to dietary recommendations appears in Table 3. Five indicated that half of the patients did not adhere to dietary recommendations, whilst three indicated the majority did not adhere to recommendations per se.

Health professionals reported that patients found it easy to use less sugar, but found food portion control the most difficult. Other areas indicated as giving patients difficulties included consuming adequate fruits and vegetables and balanced meals. This is in agreement with what was found amongst the patient group.

\section{Barriers to adhering to dietary recommendations}

Information on barriers to dietary adherence was generated through asking patients questions regarding the problems they experienced whilst making dietary changes, and what hindered them from making other changes they deemed desirable. Health professionals were asked questions on the factors they thought discouraged dietary adherence by patients.

Eight barriers to following dietary recommendations were identified (Table 4). Some of the barriers mentioned were similar amongst the patients and health professionals, whilst others differed.

Financial constraints, including food insecurity, was the major barrier identified by the two groups. All of the patient groups $(n=5)$ and all health professionals cited it as a barrier.

The social context was another barrier cited by the two groups. Family meal arrangements was seen as a barrier, either due to the fact that some patients were not in charge of food purchasing or preparation, or their condition was viewed as needing different foods.

Health professionals viewed social functions (ceremonies) and cultural beliefs as precipitators or underlying forces to inappropriate dietary practices. This was not cited in the patient group.

Barriers related to self-care were cited by both the patients and health professionals, with some aspects being similar whilst others differed. Denial of disease and use of other remedies was mentioned as common by both groups. Selfcare barriers cited only by patients included helplessness from lack of control despite perceived adherence, forgetting to eat, and the belief that dietary change is difficult. 'Cravings and temptation' was the only barrier mentioned by health professionals only.

Barriers related to perceived effects of the required dietary changes emerged from the patient group. Two of the focus groups indicated that special foods were needed, and three groups indicated that the foods were tasteless and the diet restrictive. Hunger was cited as related to the disease as well as to the requirement to eat small food portions, and therefore seen as a barrier.

Access to appropriate foods and the cost of these were barriers identified by both groups, and were associated with the physical environment. Participants cited the high cost of foods and unavailability of healthy foods in the local markets as impediments to dietary compliance.

The patients (four groups) indicated that the education they were offered at the clinic was not comprehensive and was too generalised as it was offered to them together with patients with other conditions. Health professionals cited poor understanding of the disease and diet due to low literacy levels as a barrier to adherence to dietary recommendations. 
TABLE 3: Health professionals' perspectives on patients' adherence to dietary recommendations $(N=10)$.

\begin{tabular}{|c|c|c|}
\hline Adherence aspect & Sub-category & $n$ \\
\hline \multirow[t]{3}{*}{ Proportion of patients not adhering to dietary recommendations } & Half & 5 \\
\hline & Majority & 3 \\
\hline & Quarter & 2 \\
\hline \multirow[t]{4}{*}{ Dietary recommendations that patients find easy to follow } & Eating three meals per day & 1 \\
\hline & Not using a lot of sugar in tea & 4 \\
\hline & Using less sugar rather than no sugar & 4 \\
\hline & Using correct cooking methods & 1 \\
\hline \multirow[t]{6}{*}{ Dietary recommendations that patients find difficult to follow } & Eating smaller portions & 5 \\
\hline & Using whole meal products & 2 \\
\hline & Using low-fat products & 4 \\
\hline & Including snacks & 3 \\
\hline & Consuming balanced diet & 5 \\
\hline & Consuming adequate fruits and vegetables & 4 \\
\hline
\end{tabular}

$n$, Given as number of patients.

TABLE 4: Summary of barriers to following dietary recommendations.

\begin{tabular}{ll}
\hline Barrier category & Sub-category \\
\hline Financial constraints and food insecurity & Lack of money, food, poverty and unemployment
\end{tabular}
Ethnographic descriptions

Financial constraints and food insecurity Lack of money, food, poverty and unemployment 'We do not have money to buy the right foods for our illness' (Gp 3, P2/8). 'Sometimes it is not a question of tablets but a lack of food' (Gp 4, P2/4).

'Because of unemployment and poverty the people are unable to buy the food they are taught to eat' (HP5).

Need for grants and food parcels

Social context

Conflict between family meal arrangements

Ceremonies

Cultural beliefs

Self care and adherence Helplessness and frustration from lack of contro despite adherence

Forgetting to eat

Use of other remedies

Denial of disease

Special foods

Tasteless foods

Restrictive diet

Hunger

Expensive foods

Access to appropriate foods

Incomprehensive and generalised education

Education not specific for diabetics

Not offered full information

Poor understanding of disease
Low education level and/or not able to read
'Not all patients afford to buy the food they are supposed to eat' (HP3).

'Help with social grants and food parcels such as maize meal, beans and milk' (Gp 5, P1/4).

'Our children cook for us, they like oily food' (Gp 2, P1/10).

'I am the only one with diabetes, they do not eat what I eat' (Gp 1, P3/5).

'They eat whatever the family members are eating because some of them are not the ones who cook' (HP3).

'During ceremonies they are tempted to eat a lot of sweets and large quantities, they always indulge' (HP7).

'Majority state they crave for sweet foods especially during wedding ceremonies' (HP4).

'Believe they are bewitched' (HP2).

'I try to be on diet, but my weight remains the same' (Gp 1,P2/5).

'Some people are loyal to the treatment only to find there is no change' (Gp 3, P1/8).

'We work in such a way that we forget to eat' (Gp 1).

'I also used herbal medicine but it did not work' (Gp 2, P6/10).

'Beliefs as most of them tend to use home remedies forgetting taking medicine and correct diet' (HP10).

'It's been long with this illness, I did not want to accept the situation' (Gp 2, P4/10).

'Denial makes them not disclose the condition, thus eat whatever is offered' (HP4).

'If it is possible one should have foods different from other family members, this will help you follow the rules' (Gp 5, P4/4).

'We are not used to these tasteless foods' (Gp 3, P1/8).

'I felt the change because we no longer enjoy nice food' (Gp 4, P2/4).

'Only that I cannot have cold drinks' (Gp 5, P3/4).

'Food is important in this illness because we feel hungry more often' (Gp 3, P1/8).

'I eat more food than expected because I feel hungry all the time' (Gp 1, P5/5).

'I have to eat small amount, thus I do not feel full' (Gp 1, P1/5).

'The foods that are good for us are expensive and sometimes we do not get them in the shops' (Gp 4, P1/4).

'I have to get the right cheese and it is difficult because it is far where I can get it' (Gp 3, P2/8).

'They are unable to do self gardening because of lack of water' (HP5).

'Environmental issues, for example, low fat products are not always available' (HP2).

'On the other hand things are being generalised as we are taught with other conditions' (Gp 1, P1/5).

'When we are with patients with other diseases we are not given full information' (Gp 3, P3/8).

'Low level of education, thus they cannot understand fully' (HP2).

'Educational background, many are not educated' (HP6). 
TABLE 5: Summary of facilitators to following dietary recommendations.

\begin{tabular}{|c|c|c|}
\hline Facilitator category & Sub-category & Ethnographic descriptions \\
\hline \multirow[t]{4}{*}{ Education } & Knowledge of suitable and unsuitable foods & 'We were advised on what to eat and not eat' (Gp 4, P1/4). \\
\hline & Guidelines with meal plan & $\begin{array}{l}\text { 'I changed the way I used to eat and followed how it was organised in the certificate from } \\
\text { hospital, my sugar went down' (Gp 2, P6/10). }\end{array}$ \\
\hline & Knowledge about disease & 'We are given good advice at the clinic' (Gp 1, P3/5). \\
\hline & & 'Knowledge about diabetes and the right foods' (HP8). \\
\hline \multirow[t]{5}{*}{ Social support } & Support by family & 'We are being supported by our children' (Gp 3, P1/8). \\
\hline & & 'Family support, the family eats the same food, thus no feeling of isolation' (HP1). \\
\hline & Support by health professionals & 'If you come across a question bring it to the clinic for the sister's explanation' (Gp 3, P2/8). \\
\hline & & 'Encouragement by health professionals during individual consultations' (HP7). \\
\hline & Peer support group & 'Having support groups where they share experiences' (HP3). \\
\hline
\end{tabular}

Gp, Group; P, participants; HP, Health professional.

TABLE 6: Summary of recommendations for an NE programme.

\begin{tabular}{|c|c|c|}
\hline Category & Sub-category & Ethnographic descriptions \\
\hline \multirow[t]{7}{*}{ Content } & Causes of diabetes and symptoms & $\begin{array}{l}\text { 'Know more about the causes of the disease and what symptoms to look for, some people } \\
\text { have different symptoms' (Gp 3, P2/8). }\end{array}$ \\
\hline & Complications of diabetes & $\begin{array}{l}\text { 'It would be good to be reminded of the problems that are caused by diabetes' (Gp 4, P1/4). } \\
\text { 'Education about their condition and the complications' (HP7). }\end{array}$ \\
\hline & More about food and what not to eat & 'More about food and what not to eat' (Gp 5, P1/4). \\
\hline & & 'Know more about food as we have problem getting the right kind of food' (Gp 2, P1/10). \\
\hline & Balanced diet & 'Eating healthy, well balanced diet' (HP5). \\
\hline & Portion size control & 'Emphasise on reducing the amount of food they are eating' (HP3). \\
\hline & Role of food in the management of diabetes & $\begin{array}{l}\text { 'They should be taught how food affects diabetes and the dangers of not eating the right } \\
\text { foods' (HP10). }\end{array}$ \\
\hline \multirow[t]{4}{*}{ Delivery format } & Group & 'I would like to be taught together with others' (Gp 1, P3/5). \\
\hline & & 'When we are together we give each other advice' (Gp 4, P1/4). \\
\hline & & 'Clients understand better if given information in a group, individual can threaten them' (HP5). \\
\hline & Both group and individual & $\begin{array}{l}\text { 'Group helps to teach many of them, individual helps to open up issues they will not in a } \\
\text { group' (HP6). }\end{array}$ \\
\hline \multirow{2}{*}{ Teaching method } & & 'Demonstrations for them to see examples of foods and amounts to serve' (HP7). \\
\hline & & 'They should be given tasks to do concerning their condition' (HP5). \\
\hline \multirow[t]{2}{*}{ Teaching material } & Written materials & $\begin{array}{l}\text { 'Some give us information but we forget; when I have a pamphlet, my children can help me' } \\
\text { (Gp 3, P1/8). }\end{array}$ \\
\hline & & 'Pamphlets they can see pictures or information and share with family' (HP7). \\
\hline Educator & Health professional and peers & 'Someone who knows about the disease, like a doctor or nurse' (Gp 5, P2/4). \\
\hline & & 'They do not participate well if someone from higher levels is not involved' (HP10). \\
\hline & & 'Peers will be useful as they have a lot of influence' (HP4). \\
\hline Venue & Community accessible sites & 'We prefer the clinic, if you call people to another place, they might not come' (Gp 1, P1/5). \\
\hline \multirow[t]{4}{*}{ Special issues } & Involve family members & 'Our children should be involved in the lessons because they cook for us' (Gp 2, P2/10). \\
\hline & & 'Educate family members about the disease and its treatment' (HP1). \\
\hline & Diabetes specific and comprehensive education & 'We prefer a person who can tell us about diabetes only' (Gp 4, P2/4). \\
\hline & & $\begin{array}{l}\text { 'When we are with other diseases we are not given full information' } \\
\text { (Gp 5, P4/4) }\end{array}$ \\
\hline
\end{tabular}

Gp, Group; P, participants; HP, Health professional.

\section{Facilitators to following dietary recommendations}

Information on facilitators to dietary adherence was generated through asking patients questions on what helped them or would help them follow dietary advice. Health professionals were asked to explain the factors that contributed to or would contribute to patients' adherence to dietary recommendations.

A summary of the facilitators to following dietary recommendations as expressed by the patients and health professionals appears in Table 5.

Social support from family and health professionals and knowledge acquired through education were identified as major facilitators to following dietary recommendations by both the patients and health professionals. Knowledge of the appropriate and inappropriate foods was considered an important aspect in dietary self-care. In one of the groups a participant stated that a written meal plan assisted in following the recommendations.

Health professionals recommended formation of support groups (peer groups), as they felt that this would facilitate appropriate self-care through sharing experiences.

\section{Recommendations for an NE programme}

Patients were asked about the kind of information they had received in the past, and the extra information they would 
need; how they would like the information to be given and by whom; when, how often and where they would like to receive the information; and other suggestions for an NE programme. Health professionals were asked to give their suggestion for content, delivery format, facilitator, teaching materials, venue and frequency of meetings and additional suggestions.

The recommendations for an NE programme as suggested by the patients and health professionals are summarisd in Table 6. Both groups' recommended topics related to the disease and diet. The patient group was not explicit with respect to nutrition topics. The health professionals gave a wide range of nutrition topics, including balanced diet, portion-size control, meal distribution, starches and the role of food in the management of the disease.

Most of the patient groups preferred delivery of education through a group format, whilst the health professionals recommended a combination of both groups and individual meetings. The patients' preference for a group format seemed to be based on the practice at the clinics: 'we are usually taught in a group'. The patients viewed the group setting as a place to learn from one another: 'when we are together we give each other advice'. The health professionals viewed the group format as less threatening to the patients, hence encouraging more participation, whilst the individual format would help them disclose issues they would not share in a group.

The patients perceived the health professional as the best person to deliver the education. Most of the health professionals indicated that the health professional or community worker in conjunction with a peer would be best suited to offer the education. They viewed the health professional or community worker as an authority figure that would motivate participation in the NE, whilst a peer would influence learning through sharing experiences.

The patients viewed the clinic as the best venue for receiving the education, and weekdays as the suitable time to receive the education. However, they were vague concerning the frequency of meetings. The health professionals gave a wide range of suggestions for frequency of meetings, with the majority $(n=5)$ indicating once per week. However, only one gave the reason for this suggestion: 'they do not like coming often due to finances'.

Posters and pamphlets were mentioned by the patients and health professionals as materials suitable for use in NE. Pamphlets were seen as materials that were useful even for those without diabetes, and for use at home with the help of family members.

Health professionals viewed participatory methods such as discussions and demonstrations as the best teaching methods.

The patients and health professionals made other recommendations, e.g. inclusion of family members in the NE and punctuality of the educators. The patients also recommended education specific to diabetes and a competent educator. The health professionals recommended use of the local language or an interpreter, and inclusion of motivational activities such as competitions.

\section{Discussion}

This qualitative study aimed at establishing the NE needs of type 2 diabetic patients as perceived by patients and their healthcare providers. The study highlights the problems and issues of concern related to diabetes and diet, and the preferences regarding $\mathrm{NE}$ from the standpoint of the participants. The results obtained provide insight for planning an NE programme that is tailored to the needs and abilities of the patients.

The results are discussed as per the study objectives, namely the current understanding of diabetes and its management, the self-reported current dietary practices and perceived dietary adherence, the factors that could impact the NE (barriers and facilitators to dietary compliance), and recommendations for content and preferred education approaches for the NE programme.

\section{Knowledge about diabetes and its treatment}

Patients in this study demonstrated some knowledge about the disease and its treatment, but not in totality. Knowledge deficits and misconceptions about the causes, metabolic consequences, complications and the relationship between diet and disease were common. This finding confirms previous reports regarding patient knowledge of the disease and its treatment (Holmstrom \& Rosenqvist 2005; Badruddin et al. 2002; Nthangeni et al. 2001). The inaccuracy and deficiency in knowledge may be due to lack of specific and comprehensive education, as indicated by the patients, and poor understanding related to low literacy levels. Although knowledge by itself does not necessarily lead to improved self-care behaviours or outcomes (Norris et al. 2001), an understanding of the disease, its course and treatment and how all these interact are pre-requisites for effective selfcare (Golay et al. 2008; Persell et al. 2004). Some studies have also demonstrated a positive relationship between disease knowledge and self-care behaviours (Van den Arend et al. 2001; Persell et al. 2004) and glycaemic control (Colleran, Starr \& Burge 2003; Persell et al. 2004). This clearly demonstrates a need for improving the basic knowledge about the disease and its treatment. The fact that patients recommended topics about the disease (causes, metabolic consequences, differences in symptoms and problems associated with the disease) further confirms a perception of inadequate knowledge about the disease.

\section{Diet knowledge, dietary practices and adherence}

An interesting finding from the study is that most of the patients seemed aware of the dietary recommendations and also indicated they had made dietary changes in line with the recommendations (Department of Health 2005; Vorster 2001). Despite these results, $80 \%$ of the health professionals 
indicated that half or more of their patients did not adhere to the dietary recommendations all of the time. In addition, self-reported dietary practices also revealed problems with intake of sufficient fruits and vegetables, portion size control, regularity of meals and consumption of balanced meals. Other problems included use of saturated fats, inappropriate management of hypoglycaemia and misconceptions about snacks. The problem with food portion control was cited in a study in a similar context (Nthangeni et al. 2001). Notable too is that most of the problems observed in the patients' reported dietary practices are similar to those reported by the health professionals. Health professionals particularly emphasised the problem of food portion control. This was also observed in the study by Shultz et al. (2001) involving diabetes educators and type 2 diabetic patients. The findings thus indicate a gap between dietary recommendations awareness and practice which could be attributed to the barriers identified in this study population.

Inadequate intake of fruits and vegetables in this study population confirms a problem identified by other studies in developed (Nelson, Reiber \& Boyko 2002) as well as developing countries (Badruddin et al. 2002).

\section{Barriers and facilitators to adhering to dietary recommendations}

The results on barriers to following dietary recommendations are striking, revealing personal and environmental factors that make it difficult for patients to make dietary changes or to adhere to dietary recommendations. Financial problems, food insecurity as well as the cost of appropriate foods were strongly emphasised by the patients and the health professionals. This is an expected result as the majority of the patients are unemployed. The findings on financial constraints and the cost of foods are in line with other previous studies (Jazayeri \& Pipelzadeh 2006; Carbone et al. 2007; Nthangeni et al. 2001; Marcy, Britton \& Harrison 2011).

Absence of support in the social environment can cause difficulties for diabetic patients when coping with illness in everyday life (Albright, Parchman \& Burge 2001). Family dietary behaviour was seen as a challenge due to family food preferences, food selection and preparation. Patients expressed reluctance by family members to make dietary changes since they were considered to be only for the diabetic person. This result is similar to other studies in different cultures (Jazayeri \& Pipelzadeh 2006; Carbone et al. 2007; Wen, Parchman \& Shepherd 2004; Albarran et al. 2006; Shultz et al. 2001; Vijan et al. 2005). Notably, social functions such as ceremonies were a barrier cited only by the health professionals. Although these may not be seen as an issue by the patients, this information forms a platform for exploring this barrier with the patients. Some studies have indicated that patients find it difficult to adhere to their diet during special occasions (Vijan et al. 2005).

The physical environment was seen as a barrier to accessibility and availability of healthful foods. This relates to the distant location of those supermarkets and/or grocery stores with a variety of and appropriate products, high cost of healthy foods in the local shops (Albarran et al. 2006; Marcy et al. 2011) and inconsistent availability of water that discourages gardening. This is an important finding since geographical areas such as neighbourhoods can influence the ability of the target audience to implement nutrition messages received (Viswanath \& Bond 2007).

Barriers that have also been identified in other studies include generalised and incomprehensive education (Nagelkerk, et al. 2006; Vincent et al. 2006; Albarran et al. 2006), feeling hungry, small food portion sizes (Vijan et al. 2005, Shultz et al. 2001), taste of the food, restrictive diet (Dye et al. 2003), forgetting to eat and inadequate knowledge of the disease and diet (Nagelkerk et al. 2006; Nthangeni et al. 2001).

Three key facilitators to following dietary recommendations emerged from the two groups of participants: family support, health professionals' support, and knowledge obtained through education. These findings have been reported in other studies (Chlebowy, Hood \& LaJoie 2010) with diabetic patients and indicate that patients in this study value education. Carbone et al. (2007), in a study of perspectives of Latino patients and their health care providers about diabetes self-management, found similar results about support by family and health professionals. A review by Gallant (2003) reported a modest positive relationship between social support and chronic disease self-management, especially in diabetes. Dietary behaviour was indicated to be particularly susceptible to social influences. Other studies have also shown a positive relationship between social support and self-care behaviours (Albright et al. 2001; Wen et al. 2004). This finding has important implications in planning care for this study population.

Overall, the family was seen both as a barrier and facilitator to dietary self-management by the two groups of participants, a result also identified by Carbone et al. (2007).

\section{Recommendations for an NE programme}

Patients and health professionals demonstrated an interest in having an NE programme and gave several suggestions on the kind of programme they preferred. Patients had clear recommendations concerning certain aspects of the programme, whilst they had difficulty articulating others.

A surprising finding concerning topics for the NE is that the majority of the patients strongly emphasised topics related to the disease, whilst they were not explicit on topics to do with diet, as indicated by statements such as 'any information that can help us feel better', and 'more about food'. This finding could be attributed to the fact that the patients perceived themselves as more deficient in knowledge about the disease than about diet. In addition, the fact that many suggested provision of grants or food parcels to help them follow dietary recommendations may 
be an indication that food insecurity was seen as the major issue that needed to be addressed.

The patients also found it difficult to recommend preferred teaching methods. Other studies using focus groups have also found an inability of patients to articulate the content of an education programme (Benavides-Vaello et al. 2004; Blancard et al. 1999). The study by Benavides-Vaello et al. (2004) found that patients who had not been exposed to diabetes education found it difficult to define what they needed to know and how best they could learn. This could be true for this study population, who indicated that they were offered education together with other chronic disease patients.

The health professionals suggested a range of topics related both to the disease and diet, most of which reflected the problems identified in the dietary practices and knowledge of the patients.

Patients envisioned a programme at the clinic, since this was seen as a familiar and accessible site. They also preferred group education as they could learn from each other. This finding has also been reported in other studies (Brown \& Hanis 1999; Dye et al. 2003). The health professionals concurred with the group education format, although most suggested a combination of both individual and group delivery as each has unique potential in enhancing learning. A combination of the two approaches is supported in interventions to promote diabetes self-management (Brown 1999).

Knowledgeable educators such as a health professional and specific but comprehensive education were indicated as desirable characteristics of the programme by the patients. This finding has been cited in other studies (Brown \& Hanis 1999; Rosal et al. 2004; Vincent et al. 2006). The health professionals also indicated that inclusion of a peer educator would further enhance learning, which is also supported by other studies (Vincent et al. 2006).

Written material, especially pamphlets, were seen as useful reinforcements of knowledge at home with the help of family. This finding has been observed in other studies (Brown \& Hanis 1999; Vincent et al. 2006). A notable finding is the recommendation to include family members in the education, a suggestion also articulated by the health professionals. This finding is consistent with other studies with type 2 diabetic patients (Brown \& Hanis 1999; Vincent et al. 2006).

\section{Practical implications}

The results obtained from this study provided insight that can be used for planning an NE programme that is tailored to the needs and abilities of the patients. The data obtained are valuable in planning education programmes for diabetic adults in other similar settings. The gap between dietary recommendations awareness and practices reported by the patients indicates the need for constant identification of barriers to self-care by healthcare providers in order to offer appropriate support.

\section{Strengths and limitations of the study}

The use of patients as well as their healthcare providers is an important strength of this study. Similar views add weight to the issue at hand, whilst divergent views complement those of the patients. The divergent information also creates a platform for further exploration of the issue with the patients. The health professionals also provided insight into some issues that patients had difficulty articulating.

The small convenient sample used in this study may not be representative of the population, and this may limit the generalisability of the results.

The use of interviews with the health professionals, as planned initially, would have given deeper insight into the issues at hand than the open-ended questionnaires. This is because with interviews one is able to probe and clarify issues (Greef 2005; Babbie et al. 2001). However, work schedules and limited staff at the clinics made it difficult to arrange for interviews. Open-ended questionnaires provided an alternative method where the health professionals could provide their views at their convenience.

In the exploration of dietary practices the reported dietary changes were not quantitatively verified. The reporting on dietary intake was mainly on the type of foods and frequency of consumption, and not the exact amounts of foods or drinks consumed. Thus the reported reduction in intake of sugar, fats and salt and portion sizes could be subjective. However, since the objective of the study was to gain insight into the nutritional issues that warrant intervention, qualitative analysis of dietary practices was deemed sufficient.

\section{Conclusion and recommendations}

The findings from this study revealed knowledge deficits and misconceptions about diabetes and its treatment in the patients. They also reported unsatisfactory dietary practices despite their general awareness of the dietary recommendations. The numerous barriers identified in this study are likely to be the major contributing factors to the gap between awareness and practice. These barriers are mainly in the personal, socio-economic and physical environment domains. Social support was the major facilitator to following dietary recommendations, with family support being seen as both a barrier and a facilitator.

Participants in this study showed interest in an NE programme, and gave specific recommendations including the clinic as the preferred site, group education, a competent educator, provision of pamphlets and inclusion of family members. The health professionals' input complemented the recommendations by the patients.

The planned NE programme should address the knowledge gaps and dietary practice problems and include strategies to address the barriers. It should also incorporate the suggestions for an NE programme as well as facilitators to dietary adherence. 


\section{Acknowledgements}

We thank all the patients and health professionals who participated in this study. Theodorah Modise (RD) is grateful acknowledged for conducting the focus group discussions. This study was supported by research grants from the South African Sugar Association \& Nestlé Nutrition Institute Africa.

\section{Competing interests}

The authors declare that they have no competing interests.

\section{Author's contribution}

P.R was the study leader and was involved in editing the manuscript. G.J.G was co-study leader, made conceptual contributions, provided theoretical expertise and edited the manuscript. J.W.M made conceptual contributions, compiled and wrote the manuscript and searched for reference material. All authors read and approved the final manuscript.

\section{References}

Albarran, N.B., Ballesteros, M.N., Morales, G.G. \& Ortega, M.I., 2006, 'Dietary behaviour and type 2 diabetes', Patient Education \& Counseling 61, 191-199. http://dx.doi.org/10.1016/j.pec.2005.03.008

Albright, T.L., Parchman, M. \& Burge, S.K., 2001, 'Predictors of self-care behaviour in adults with type 2 Diabetes: An RRNeST Study', Family Medicine 33(5), 354-360.

American Dietetic Association, 1996, 'Nutrition education for the public', Journal of the American Dietetic Association 96(11), 1183-1187.

Anderson-Loftin, W., Barnett, S., Sullivan, P., Bunn, P.S. \& Tavakoli, A., 2002, 'Culturally competent dietary education for southern rural African Americans', Diabetes Educator 28(2), 245-257. http://dx.doi.org/10.1177/014572170202800210

Babbie, E.R., Mouton, J., Vorster, P. \& Prozesky, B., 2001, The practice of social research, Oxford University Press, Cape Town.

Badruddin, N., Basit, A., Hydrie, M.Z.I. \& Hakeem, R., 2002, 'Knowledge, attitudes and practices of patients visiting a diabetes care unit', Pakistan Journal of Nutrition 1(20), 99-102.

Benavides-Vaello, S., Garcia , A.A., Brown, S.A. \& Winchell, M., 2004, 'Using focus groups to plan and evaluate diabetes self-management interventions focus groups to plan and evaluate diabetes self-management interventions
for Mexican Americans', Diabetes Educator 30(2), 238-256. http://dx.doi. org/10.1177/014572170403000217

Blancard, M.A., Rose, L.E., Taylor, J., McEntee, M.A. \& Latchaw, L.L., 1999 Using focus groups to design a diabetes education program for an African American population', Diabetes Educator 25(6), 917-925. http://dx.doi. org/10.1177/014572179902500609

Brown, S.A. \& Hanis C.L., 1999, 'Culturally competent diabetes education for Mexican Americans: The Starr Country study', Diabetes Educator 25(2), 226-236. http:// dx.doi.org/10.1177/014572179902500208

Brown, S.A., 1999, 'Interventions to promote diabetes self-management: state of art science', Diabetes Educator 25(6), S52-S61.

Brown, S.A., Garcia, A., Koukezani, K. \& Hanis, C.L., 2002, 'Culturally competent diabetes self-management education for Mexican Americans: The Star County Border Health Initiative', Diabetes Care 25(2), 259-268. http://dx.doi. org/10.2337/diacare.25.2.259

Carbone, E.T., Rosal, M.C., Torres M. I., Goins, K.V. \& Bermudez, I.I., 2007, 'Diabetes self-management: perspectives of Latino patients and their health care providers', Patient Education \& Counseling 66, 202-210. http://dx.doi.org/10.1016/j. pec.2006.12.003

Chlebowy, D.O., Hood, S. \& LaJoie, S., 2010, 'Facilitators and barriers to self-management of type 2 diabetes among urban American adults: Focus group findings', Diabetes Educator 36(6), 897-905. http://dx.doi.org/10.1177/0145721710385579

Clark, M., Hampson, S.E., Avery, H. \& Simpson, R., 2004, 'Effects of a tailored lifestyle self management intervention in patients with type 2 diabetes mellitus', British Journal of Health Psychology 9(3), 365-379. http://dx.doi. org/10.1348/1359107041557066

Colleran, K.M., Starr B. \& Burge, M.R., 2003, 'Putting Diabetes to the Test. Analyzing glycemic control based on patients' diabetes knowledge', Diabetes Care 26(7), 2220-2221. http://dx.doi.org/10.2337/diacare.26.7.2220

Cox, R.H., Carpenter, J.P., Bruce, S.A., Poole, K.P. \& Gaylord, C.K., 2004, ' Characteristics of low-income African-American and Caucasian adults that are important in selfmanagement of type 2 diabetes', Journal of Community Health 29(2), 155-577. http://dx.doi.org/10.1023/B:JOHE.0000016719.89848.b1

Department of Health, Directorate of Chronic Diseases, Disabilities \& Geriatrics, 2005, National guideline: Management of diabetes type 1 and type 2 in adults a hospital level, Annexure 4, pp. 46-47, Depatment of Health, Pretoria.

Dye, C.J., Haley-Zitlin, V. \& Willoughby, D., 2003, 'Insights from older adults with type 2 diabetes: Making dietary and exercise changes', Diabetes Educator 29(1), 116127. http://dx.doi.org/10.1177/014572170302900116
Ellis, E.E., Speroff, T., Dittus, R.S., Brown, A., Pichert, J.W. \& Elasy, T.A., 2004, 'Diabetes patient education: A meta-analysis and meta-regression', Patient Education \& Counseling 52, 97-105. http://dx.doi.org/10.1016/S0738-3991(03)00016-8

Fouche, C.B., 2005, 'Qualitative research designs', in A.S. De Vos, H. Strydom, C.B. Fouche \& C.S.L. Delport (eds.), Research at the grass root for the social sciences and human service professions, 3rd edn., pp. 263-273, Van Schaik Publishers, Pretoria.

Funnell, M.M., Brown, T.L., Childs, B.P., Haas, L.B., Hosey, G.M., Jensen, B. et al., 2009 'National standards for diabetes self-management education', Diabetes care 32, suppl. 1, S87-S94. http://dx.doi.org/10.2337/dc09-S087

Gallant, M.P., 2003, 'The influence of Social support on chronic illness selfmanagement: A review and directions for research', Health Education \& Behaviour 30(2), 170-195. http://dx.doi.org/10.1177/1090198102251030

Glazier, R.H., Bajcar, J., Kennie, N.R. \& Wilson, N.K., 2006, 'A systematic review of interventions to improve diabetes care in socially disadvantaged populations', Diabetes Care 29(7), 1675-1688. http://dx.doi.org/10.2337/dc05-1942

Golay, A., Lagger, G., Chambouleyron, M., Carrard, I. \& Lasserre-M., 2008, 'Therapeutic education of diabetic patient', Diabetes/Metabolism Research \& Reviews 24, 192 196. http://dx.doi.org/10.1002/dmrr.798

Greef, M., 2005, 'Information collection: interviewing', in A.S. De Vos, H. Strydom, C.B. Fouche \& C.S.L Delport (eds.), Research at the grass root for the social sciences and human service professions, 3rd edn., pp. 286-313, Van Schaik Publishers, Pretoria.

Gwatkin, D., Guillot, M. \& Heuveline, P., 1999, 'The burden of disease among the global poor', Lancet 354, 586-589. http://dx.doi.org/10.1016/S0140-6736(99)02108-X

Holmstrom, I. \& Rosenqvist, U., 2005, 'Misunderstanding about illness and treatment among patients with type 2 diabetes', Journal of Advanced Nursing 49(2), 146154. http://dx.doi.org/10.1111/j.1365-2648.2004.03274.x

International Diabetes Federation, 2009, 'International standards for diabetes education', 3rd edn., viewed 19 April 2012, from http://www.idf.org/files/docs/ INTNL-STANDARDS-EN.pdf

International Diabetes Federation, 2011, 'Types of diabetes', viewed 19 April 2012 from http://www.idf.org/types-diabetes.

Jazayeri, S.M.H.M. \& Pipelzadeh, M.H., 2006, 'Barriers to diet self-care in outpatients with type 2 diabetes in Iran', Pakistan Journal of Medical Sciences 22(4), 412-415.

Kidd, P.S. \& Parshall, M.B., 2000, 'Getting the focus and the group: Enhancing analytical rigor in focus group research', Qualitative Health Research 10(3), 293. http://dx.doi.org/10.1177/104973200129118453

Levetan, B.N., Levitt, N.S. \& Bonnici, F., 1997, 'Hyperglycemic emergencies are a common problem', South African Medical Journal 87, 368-370.

Lopez, K.A. \& Willis, D.G., 2004, 'Descriptive versus interpretive phenomenology: Their contributions to nursing knowledge', Qualitative Health Research 14(5), 726-735. http://dx.doi.org/10.1177/1049732304263638

Marcy, T.R., Britton, M.L. \& Harrison, D., 2011, 'Identification of barriers to appropriate dietary behaviour in low-income patients with type 2 diabetes mellitus', Diabetes Therapy 1(2), 1-11.

Moretele Local Municipality, 2008/2009, Reviewed integrated development plan (IDP), Moretele Local Municipality, Makapanstad.

Muchiri, J.W., Gericke, G. \& Rheeder, P., 2009, 'Elements of effective nutrition education for adults with diabetes mellitus in resource-poor settings: A review', HealthSA Gesondheid 14(1), viewed 21 June 2011, from http://dx.doi. org/10.4102/hsag.v17i1.621

Nagelkerk, J., Reick, K. \& Meengs, L., 2006, 'Perceived barriers and effective strategies to diabetes self-management', Journal of Advanced Nursing 54(2), 151-158. http://dx.doi.org/10.1111/j.1365-2648.2006.03799.x

Nelson, K.N., Reiber G. \& Boyko E.J., 2002, 'Diet and exercise among adults with type 2 diabetes: Findings from the third National Health and Nutrition Examination Survey (NHANES III)', Diabetes Care 25(10), 1722-1728. http://dx.doi. org/10.2337/diacare.25.10.1722

Norlyk, A. \& Harder, I., 2010, 'What makes a phenomenological study phenomenological? An analysis of peer-reviewed empirical studies', Qualitative Health Research 20(3), 420-431. http://dx.doi.org/10.1177/1049732309357435

Norris, S.L., Engelgau, M.M. \& Narayan, K.V., 2001, 'Effectiveness of self-management training in type 2 diabetes: A systematic review of randomized controlled trials', Diabetes Care 24(3), 561-587.

Norris, S.L., Lau, J., Smith, S.J., Schmid, C.H. \& Engelgau, M.M., 2002, 'Selfmanagement education for adults with type 2 diabetes: a meta-analysis of effect on glycemic control', Diabetes Care 25(7), 1159-1171. http://dx.doi.org/10.2337/ diacare.24.3.561

Nthangeni, G., Steyn, N.P., Alberts, M., Steyn, K., Levitt, N.S., Laubscher, R. et al., 2001 Dietary intake and barriers to dietary compliance in black type 2 diabetic patients attending primary health-care services', Public Health Nutrition 5(2), 329-338.

Pastors, J.G., Warshaw, H., Daly, A., Franz, M. \& Kulkani, K., 2002, 'The evidence for the effectiveness of medical nutrition therapy in diabetes management', Diabetes Care 25(3), 608-613. http://dx.doi.org/10.2337/diacare.25.3.608

Persell, S.D., Keating, N.L., Landrum, M.B., Landon, B.E., Ayanian, J.Z., Borbas, C. et al., 2004, 'Relationship of diabetes-specific knowledge to self-care activities, ambulatory preventive care and metabolic outcomes', Preventive Medicine 39 764-752. http://dx.doi.org/10.1016/j.ypmed.2004.02.045

Rabiee, F., 2004,'Focus-group interview and data analysis', Proceedings of the Nutrition Society 63, 655-660. http://dx.doi.org/10.1079/PNS2004399

Roper, N.A., Bilous, R.W., Kelly, W.F., Unwin, N.C. \& Connolly, V.M., 2001, 'Excess mortality in a population with diabetes and the impact of material deprivation: mortality in a population with diabetes and the impact of material deprivation: Longitudinal, population based study', British
http://dx.doi.org/10.1136/bmj.322.7299.1389

Rosal, M.C., Goins, K.V., Carbone, E.T. \& Cortes, D.E., 2004, 'Views and preferences of low-literate Hispanics regarding education: Results of formative research', Health Education \& Behavior 31(3), 388-405. http://dx.doi. org/10.1177/1090198104263360 
Shabbidar, S., Fathi, B. \& Shirazifard, N.M., 2006, 'Effects of clinical nutrition education on glycemic control outcomes in type 2 diabetes', International Journal of Diabetes
in Developing Countries 26(4), 165-169. http://dx.doi.org/10.4103/0973in Developing

Shaw, J.E., Sicree, R.A. \& Zimmet, P.Z., 2010, 'Global estimates of the prevalence of diabetes for 2010 and 2030', Diabetes Research and Clinical Practice 87(1), 4-14. http://dx.doi.org/10.1016/j.diabres.2009.10.007

Shultz, J.A., Sprague, M.A., Branen, L.J. \& Lambeth, S., 2001, 'A comparison of views of individuals with type 2 diabetes mellitus and diabetes educators about barriers to diet and exercise', Journal of Health Communication 6, 99-115. http://dx.doi. org/10.1080/108107301750254457

Speziale, H.J.S. \& Carpenter, D.R., 2007, Qualitative research in nursing. Advancing the humanistic imperative, 4th edn., Lippincott Williams \& Wilkins, Philadelphia.

Suhl, E. \& Bonsignore, P., 2006, 'Diabetes self-management education for older adults: General principles and practical application', Diabetes Spectrum 19(4), 234-240. http://dx.doi.org/10.2337/diaspect.19.4.234

Sullivan, E.D. \& Joseph, D.H., 1998, 'Struggling with behaviour changes: a special case for clients with diabetes', Diabetes Educator 24, 72-77. http://dx.doi. org/10.1177/014572179802400110

Two Feathers, J., Kieffer, E.C., Palmisano, G., Anderson, M., Guzman, N. \& James S.A. 2007, 'The development, implementation, and process evaluation of the REACH Detroit Partnership's Diabetes', Diabetes Educator 33(3), 509-520.
Van den Arend, I.J., Stolk R.P., Rutten, G.E. \& Schrijvers, G.J., 2001, 'Education integrated into structured general practice care for type 2 diabetic patients' integrated into structured general practice care for type 2 diabetic patients' 17(3), 190-197. http://dx.doi.org/10.1046/j.1464-5491.2000.00232.x

Vijan, S., Stuart, N.S., Fitzgard, J.T., Ronis, D.L., Hayward, R.A., Slater, S., \& Hofer T.P. 2005, 'Barriers to following dietary recommendations in type 2 diabetes', Diabetes Medicine 22, 32-38. http://dx.doi.org/10.1111/j.1464-5491.2004.01342.x

Vincent, B., Clark, L., Marquez, L., Zimmer, L. \& Sanchez, J., 2006, 'Using Focus Groups to develop a culturally competent diabetes self-management program for Mexican Americans', Diabetes Educator 32(1), 89-97. http://dx.doi. org/10.1177/0145721705284372

Viswanath, K. \& Bond, K., 2007, 'Social determinants and nutrition: Reflections on the role of communication', Journal of Nutrition Education \& Behaviour 39, S20-S24. role of communication', Journal of Nutrition Educ
http://dx.doi.org/10.1016/j.jneb.2006.07.008

Vorster, H.H. (ed.), 2001, 'South African Food Based Dietary Guidelines', South African Journal of Clinical Nutrition 14(3), Suppl. S1-S80.

Wen, L.K., Parchman, M.L. \& Shepherd, M.D., 2004, 'Family support and diet barriers among older Hispanic adults with type 2 Diabetes', Family Medicine 36(6), 423430.

Zimmet, P., 2003, 'The burden of type 2 diabetes: are we doing enough?', Diabetes \& Metabolism 29(4), 6S9-6S18. 